\title{
Defining Down Sovereignty: The Rights and Responsibilities of Nations
}

\author{
Amitai Etzioni
}

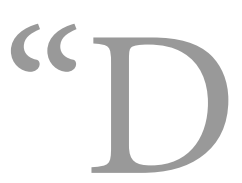

efining down sovereignty" refers to the normative thesis that sovereignty should not grant a state absolute protection against armed intervention in its internal affairs by other states, and that instead the international community should condition such immunity on states living up to particular standards. This essay suggests two modifications to this thesis. First, the international community should spell out the kinds of failures to protect civilians that can justify armed interventions by other states, as well as which agency has the authority to determine when such failures have occurred. In other words, the international community should determine how low to set the bar for intervention, and who makes the rules. Second, the international community needs to establish an additional international responsibility, namely, a responsibility to prevent international terrorism. The essay treats both of these modifications as shared international normative understandings; it does not attempt to translate these changes into international law.

The essay first briefly reviews the normative assumptions about state sovereignty that form the foundation of the international order. The next section argues that state sovereignty has never been considered absolute. The third section briefly reviews the well-known drive to define down state sovereignty by discussing the normative conception of the "responsibility to protect" (RtoP). The fourth section identifies a need to spell out the conditions under which the international community would judge that a state has failed to fulfill its responsibility to protect its civilians and that, thus, armed intervention is justified, as well as which specific authority would make such a ruling. The final part of the essay proposes a new responsibility to prevent international terrorism and argues that a state's failure

Ethics \& International Affairs, 30, no. 1 (2016), pp. 5-20.

(c) 2016 Carnegie Council for Ethics in International Affairs

doi:10.1017/So892679415000544 
to discharge it-whether because the state is unwilling or unable to act-justifies armed intervention by other states.

\section{Sovereignty as a Keystone}

Both modifications proposed by this essay concern changes to what many hold to be the most profound foundation of the international order, ${ }^{1}$ the concept of state sovereignty, which in contemporary thought and practice has been largely understood in association with the Westphalian principle that forbids armed interference by one state in the internal affairs of another. ${ }^{2}$ Respect for international borders is a crucial part of this order. They are the markers that separate that which is fully legitimate and that which most assuredly is not. If the troops of a given state are positioned within its boundaries, the international community considers them to be a legitimate part of an orderly world composed of states. The international community holds that the same troops crossing a border with hostile intentions is a severe violation of the agreed-upon world order; should this occur, the international order and the invaded state are inclined to respond violently. There are countless reports that people in very different parts of the world feel personally aggrieved, insulted, and humiliated when they learn that their state's sovereignty has been violated, even if another state's troops have simply crossed some minor or vague line in the shifting sands. ${ }^{3}$ That millions of people have shown that they are willing to die to protect their state's sovereignty is an indication of the depth of their commitment to this precept. Indeed, even when a state violates another's sovereignty to bring aid to the latter's population, strong loyalty to the sovereignty paradigm persists. As Francis Deng notes:

Whether international involvement in a domestic problem is strategically motivated or driven by humanitarian concerns, it nearly always evokes a reaction that is both appreciative of assistance and hostile to foreign intervention. It could indeed be conjectured that when the state fails to honor the responsibilities of national sovereignty, the people will retain their consciousness of pride, honor, and independence, despite their need for external help. ${ }^{4}$

The same normative idea is also tied to the strongly held precepts of selfdetermination, which played a key role in dismantling colonial empires and establishing independent nation-states. The right to state sovereignty is trumpeted by the governments and citizens of both autocracies and democracies-all of which tend to decry foreign intervention into their affairs on nationalist grounds. The respect for sovereignty ${ }^{5}$ is ensconced in a great many international laws and institutions, such as the International Criminal Court (ICC) and most notably the 
Charter of the United Nations. ${ }^{6}$ For example, the Preamble as well as Articles 17 and 53 of the Rome Statute, which established the ICC, identifies the Court's jurisdiction as complementary to the jurisdictions of its member states, which means that the ICC may only pursue cases that states are unable or unwilling to prosecute themselves. ${ }^{7}$ Article 2 of the United Nations Charter, meanwhile, states that the United Nations is based "on the principle of the sovereign equality of all its Members." 8

\section{Sovereignty Was Never Absolute}

Many criticized the Westphalian sovereignty paradigm from the start-both those who considered claims of sovereignty to be a form of idolatry and those who saw the paradigm as a shield for tyrants' abuses. ${ }^{9}$ For example, political philosopher Jacques Maritain contends that the concept of sovereignty is intrinsically faulty, as it both separates the will of the nation from that of the body politic and creates insurmountable complications for international law. ${ }^{10}$ Others like Stephen Krasner have characterized sovereignty as "organized hypocrisy," criticizing it on the grounds that it is universally recognized but, at the same time, widely violated. ${ }^{11}$ Specifically, Krasner holds that leaders endorse sovereignty when the paradigm helps them maintain their positions of power and ignore it when it is politically expedient to do so. ${ }^{12}$

Other scholars insist that sovereignty has never been considered absolute. Bertrand de Jouvenel, for example, argues that people often understand the sovereign will as being an absolute authority, but they also understand that even such absolute authority is subject to constraints of morality. ${ }^{13}$ According to this view, sovereignty rests upon a further moral framework that serves to justify the paradigm-but that can also justify deviations from and exceptions to it. Furthermore, there have always been pragmatic and principled exceptions to the self-determination component of sovereignty. For example, international law has long restricted states from carrying out "acts wholly within one state which cause damage to another state," such as using a disproportionate amount of a water source shared by other states or injuring foreign nationals and diplomats. ${ }^{14}$

In addition, the UN Charter may be taken to treat sovereignty as instrumental. "The Charter of the United Nations seeks to protect all States, not because they are intrinsically good but because they are necessary to achieve the dignity, justice, worth and safety of their citizens"-the implication being that states might forfeit their sovereignty if they fail to achieve the ends that justify state sovereignty. ${ }^{15}$ In 
the wake of World War II, a majority of states drafted and signed the 1948 Universal Declaration of Human Rights (UDHR), thereby codifying the obligation incumbent upon states to uphold their citizens' rights to be free from mass atrocity crimes and human rights abuses. Although this declaration did not include enforcement mechanisms, it gave voice to the growing normative consensus that states have an obligation to respect human rights - an obligation that is simultaneous with, and perhaps even overrides, the right to sovereignty. ${ }^{16}$ Indeed, many scholars have contended that not only does the UDHR allow violations of sovereignty norms (for example, humanitarian intervention) but that it is "fundamentally at odds with state sovereignty." " Similarly, the 1948 Convention on the Prevention and Punishment of the Crime of Genocide ("Genocide Convention") obliges states both to refrain from and work to punish genocide; two additional covenants, one on civil and political rights, the other on economic and cultural rights, followed the Genocide Convention in the mid-1960s. ${ }^{18}$ Michael W. Doyle adds that the United Nations Charter hampers unbridled state sovereignty in a whole host of ways, including in issues of international security and budget authority. ${ }^{19}$

\section{Defining Down Sovereignty: The Responsibility to Protect}

Contemporary international theory and practice is largely departing from the view that sovereignty is absolute and is instead adopting the idea of conditional sovereignty - that is, that sovereignty is contingent upon states fulfilling certain domestic and international obligations. This is largely a communitarian approach, and it is one built on a communitarian notion of citizenship. In other words, it recognizes that states (like individuals) have not only rights but also responsibilities; they are entitled to self-determination and self-government, but must also demonstrate their commitment to the common good by protecting the environment, promoting peace, and refraining from harming their population. ${ }^{20}$ Recent humanitarian crises have further called into question the inviolability of sovereignty. The international community widely accepts that states have a responsibility to refrain from committing (or allowing) mass atrocities against their citizens (for example, genocide), and that in failing to uphold such responsibilities they forfeit their sovereignty. This understanding is manifested in the Responsibility to Protect (RtoP), as adopted at the World Summit in $2005 .^{21}$ Francis Deng and his associates, in a 1996 book entitled Sovereignty as Responsibility, ${ }^{22}$ argued that when states do not conduct their domestic affairs 
in ways that meet internationally recognized standards, other states have not only a right but a duty to intervene. Deng forcefully stated this modification of the Westphalian norm and, at great length, defended his thesis that:

The sovereign state's responsibility and accountability to both domestic and external constituencies must be affirmed as interconnected principles of the national and international order. Such a normative code is anchored in the assumption that in order to be legitimate sovereignty must demonstrate responsibility. At the very least that means providing for the basic needs of its people. ${ }^{23}$

The International Commission on Intervention and State Sovereignty further developed the idea in its 2001 report The Responsibility to Protect, and centered its proposals on sovereignty as responsibility. It held that:

The Charter of the UN is itself an example of an international obligation voluntarily accepted by member states. On the one hand, in granting membership of the UN, the international community welcomes the signatory state as a responsible member of the community of nations. On the other hand, the state itself, in signing the Charter, accepts the responsibilities of membership flowing from that signature. There is no transfer or dilution of state sovereignty. But there is a necessary re-characterization involved: from sovereignty as control to sovereignty as responsibility in both internal functions and external duties. ${ }^{24}$

In 2004 the UN Secretary-General's High-level Panel on Threats, Challenges and Change (the "High-level Panel") advanced this view in its report, A More Secure World-Our Shared Responsibility, which argues that:

Whatever perceptions may have prevailed when the Westphalian system first gave rise to the notion of State sovereignty, today it clearly carries with it the obligation of a State to protect the welfare of its own peoples and meet its obligations to the wider international community. ${ }^{25}$

Here, again, the report implies that a state's willingness and capacity to fulfill its basic responsibilities and obligations preconditions its sovereignty. RtoP reaches even further; it not only holds that states must fulfill their obligations to protect their citizens from mass atrocity crimes in order to maintain their sovereignty but also holds that other states have the obligation to intervene if a state fails to uphold its responsibility to protect. $^{26}$

Before the advent of RtoP, the United Nations Security Council had authorized interventions rarely and on an ad hoc basis-for example, in Somalia and Haiti; it had not developed a general case for downgrading state sovereignty. RtoP codified 
a specific set of criteria that would justify violating a state's sovereignty-and thus significantly "walked back" the Westphalian norm. Since the United Nations General Assembly endorsed RtoP unanimously in 2006, ${ }^{27}$ "numerous resolutions by the Security Council and General Assembly" have referenced the concept, which has ascended to a place of prominence in the international debate and has been invoked by a wide range of state and nonstate actors. ${ }^{28}$ RtoP has also suffered setbacks, however, notably due to its invocation as the rationale for the 2003 invasion of Iraq and the 2011 NATO intervention in Libya, both of which weakened its support. ${ }^{29}$ Accordingly, some of RtoP's normative groundingnamely, conditional sovereignty—has been similarly eroded.

\section{How FAR Is "Down"?}

While considerable international consensus exists about RtoP, much less agreement exists about the point at which a state's neglect of its responsibilities justifies armed intervention by other states, and about which authority should determine that this point has been reached. Deng, who is credited with coining the concept of sovereignty as responsibility, holds that in order to avoid being stripped of its sovereignty a state must maintain good governance and provide for the "general welfare of its citizens and those under its jurisdiction." ${ }^{\circ}$ In his 1996 book Sovereignty as Responsibility: Conflict Management in Africa, Deng and his colleagues wrote that the only states exempt from potential intervention are those with governments that "under normal circumstances, strive to ensure for their people an effective governance that guarantees a just system of law and order, democratic freedoms, respect for fundamental rights, and general welfare." ${ }^{31}$ This formula sets the bar very low; very few states would be safe from armed intervention if the international community were to adopt Deng's guidelines. Deng does not spell out which authority should judge whether intervention is justified, but the tenor of his writing suggests he intends the Security Council or, possibly, the General Assembly to fill the role.

In the early 1990s, French diplomat Bernard Kouchner and his colleagues coined the term "le droit d'ingérence," which aimed to establish a principle that France has a right to support its nongovernmental entities in their attempts to end atrocities. ${ }^{32}$ The circumstances under which this principle would hold appeared to be based on the assessments of nongovernmental organizations as to whether they have a moral duty to offer assistance in humanitarian crises. ${ }^{33}$ 
Arguably, this set the bar even lower than Deng did. However, this principle never gained traction. Indeed, it is only very rarely mentioned in the literature.

In 1995 the Commission on Global Governance recommended that the United Nations craft legal opportunities for armed humanitarian intervention under specific circumstances. In the Commission's holding, the "acceptable basis for humanitarian action"-which it grounded in the fundamental principle that "all states have an obligation to protect [the right of all people to a secure existence]"-is extraordinarily vague: "The line separating a domestic affair from a global one [that is, one validating intervention] cannot be drawn in the sand, but all will know when it has been crossed." 34 Earlier in the document it proposed "restricting [the scope of a new Charter amendment] to cases that constitute a violation of the security of the people so gross and extreme that it requires an international response." This report set the bar higher than did Deng and specified which authority (the United Nations) would render the ruling that a state has not lived up to its responsibilities.

Another approach to the conditions under which armed humanitarian intervention may be undertaken is derived from international law. It holds that armed humanitarian intervention, as authorized by the Security Council, should be undertaken whenever a humanitarian crisis escalates to the point that it poses a "threat to international peace and security." 35 This is the justification that supported the intervention in Libya in 2011 (for example, with the establishment of a no-fly zone); in March 2011, Security Council Resolution 1973 "act[ed] under Chapter VII of the Charter" (which empowers the Security Council to "determine the existence of any threat to the peace" and to authorize collective action) and authorized "Member States that have notified the Secretary-General, acting nationally or through regional organizations or arrangements, and acting in cooperation with the Secretary-General, to take all necessary measures . . . to protect civilians and civilian populated areas under threat of attack . . . while excluding a foreign occupation force." 36 This approach focuses more on determining which agency has the authority to rule on the necessity of an intervention than on determining the degree of harm done to a population that justifies an intervention. Indeed, one scholar holds that the Security Council's "discretion to determine the existence of threats to or breaches of international peace and security is virtually absolute."37

Meanwhile, the 2001 report drafted by the International Commission on Intervention and State Sovereignty, chaired by Gareth Evans and Mohamed 
Sahnoun, spells out where to "draw the line in determining when military intervention is, prima facie, defensible." ${ }^{8}$ It offers two "threshold criteria" that constitute just cause for humanitarian intervention: "large scale loss of life, actual or apprehended, with genocidal intent or not, which is the product either of deliberate state action, or state neglect or inability to act, or a failed state situation; or large scale 'ethnic cleansing,' actual or apprehended, whether carried out by killing, forced expulsion, acts of terror or rape." ${ }^{39}$ This is by far the clearest set of criteria and does not set the bar so low that any state can claim justification for humanitarian intervention.

Several scholars agree that RtoP as adopted at the United Nations World Summit in 2005 holds states responsible for protecting their people from four "mass atrocity" crimes. ${ }^{40}$ Paragraph 138 of the Outcome Document specifically lists "genocide, war crimes, ethnic cleansing and crimes against humanity" as the four moral atrocity crimes against which a state is responsible for protecting its population. ${ }^{41}$ When states fail to live up to their responsibility to protect their civilians from mass atrocities, other states become collectively responsible for taking coercive measures to end such atrocities. These include political, economic, and juridical measures, and only in "extreme" circumstances may states resort to military intervention. Adrian Gallagher attempts to further specify these conditions by pointing out the Outcome Document's expression "manifestly failing to protect their populations." He holds that the phrase, which replaced "unable or unwilling" in the final Outcome Document for reasons unknown, is highly ambiguous; he then proposes that the international community arrive at consensus about indicators of "manifest failing," which he suggests should be "government intentions, the types of weapons used, the death toll, the number of people displaced, [and evidence of] intentional targeting of civilians, especially women, children, and the elderly." 42

Louise Arbour, former UN High Commissioner for Human Rights, meanwhile offered a very similar set of guidelines, grounded not in the United Nations Charter but rather in the Convention on the Prevention and Punishment of the Crime of Genocide, the Rome Statute of the International Criminal Court, and various war crimes tribunals. She advanced the notion that the international community should be responsible for intervening in cases of genocide ("a crime under international law which [States] undertake to prevent and to punish"), and offered a set of guidelines for determining whether a state has fulfilled this responsibility based on the rulings of the International Criminal Court. ${ }^{43}$ Namely, the state must 
essentially exercise due diligence to prevent genocide; and whether the state has exercised due diligence is, in turn, based on such factors as (but not limited to) its influence over the actors likely to commit genocide. ${ }^{44}$ Arbour's is a relatively detailed set of guidelines.

In short, if the international community authorizes the United Nations to determine whether the conditions have been met for humanitarian interventionconditions that draw on the specific criteria outlined above, which avoid excessively lowering the standard for intervention-the challenge of answering the dual question of who should judge a state's fulfillment of its duties and the specific content of those responsibilities has been met.

\section{No Coercive Regime Change}

By contrast, intervention for the purpose of regime change and nation-building should be limited to noncoercive means and should exclude the use of force. Neither adding to the set of responsibilities a state must fulfill to guarantee its sovereignty nor demanding a certain form of government at the threat of armed intervention is justified; these matters should be the purview of the people of the states involved. Intervention over these issues often results not in a free regime, but rather in new forms of authoritarianism, anarchy, or civil war. ${ }^{45}$ Pushing RtoP toward regime change threatens the fragile international consensus on intervention. Russia and China-both states that have, in the past, strongly endorsed the Westphalian norm ${ }^{46}$-have in part come to accept armed interventions for humanitarian purposes provided that those interventions do not advance other causes. ${ }^{47}$ For example, in 2006 China's then-ambassador to the United Nations endorsed RtoP as it pertains to "genocide, war crimes, ethnic cleansing and crimes against humanity," but insisted that "it is not appropriate to expand, willfully to interpret or even abuse this concept." ${ }^{48}$ Pushing for too expansive a challenge to sovereignty might, thus, sour China on the more limited responsibilities outlined above. Moreover, although ambiguity in the responsibility to protect made some states and observers worry that states would use the principle as a smokescreen to justify the pursuit of their national interests, ${ }^{49}$ as Alex J. Bellamy points out, such fears have not materialized. ${ }^{50}$

\section{The Duty to Prevent Transnational Terrorism}

It may seem obvious that if terrorists based in one nation attack the people of another nation, the forces of the attacked nation should have the right to use force against these terrorists. However, many view acts such as the use of unmanned 
aerial vehicles (UAVs) or special forces to strike transnational terrorists (that is, terrorists based in one nation attacking people in another) as violations of state sovereignty. Hence, when the United States conducted UAV strikes in Pakistan or Yemen, it typically notified the Pakistani and Yemeni governments (albeit "concurrently" ${ }^{1}$ ) or stressed that the U.S. actions had the relevant government's "tacit consent" 52 in a show of respect for the norm of state sovereignty. The international community criticized the United States for its clear violation of the sovereignty of Pakistan when American Special Forces eliminated Osama bin Laden in Abbottabad. ${ }^{53}$

International law scholar Mary Ellen O’Connell argues that “international law has a definition of war [that] refers to places where intense, protracted, organized inter-group fighting occurs. It does not refer to places merely where terrorist suspects are found." 54 She further argues that outside of the narrowly defined theaters of war, spelled out in declarations of war by the nations involved, the "law of peace" should guide counterterrorist efforts. ${ }^{55}$ Along similar lines, other scholars maintain that it is never permissible, according to the UN Charter, to militarily infringe upon another state's territorial sovereignty in order to deal with a nonstate threat. $^{56}$

Moreover, until the late 1980s, terrorist acts were considered to be outside the jurisdiction of the Security Council, meaning that states had little recourse in responding to transnational terrorism within the purview of international law. Still, the Security Council and General Assembly condemned the Israeli attack on the Palestine Liberation Organization headquarters in $1985^{57}$ and the American strike against Libyan targets in $1986 .^{58}$ Both of these responses to transnational terrorism (past and anticipated) were deemed violations of the international norms of state sovereignty. In 2004, Security Council Resolution 1566 addressed the issue of terrorism as criminal activity, and hence a matter to be handled by local law enforcement authorities, rather than as conduct associated with war. ${ }^{59}$ And in 2006, the United Nations adopted a Global Counter-Terrorism Strategy to combat terrorism using a criminal law model. ${ }^{60}$ The United Nations thus considers illegal "the possibility that states could lawfully resort to forcible measures against terrorists based in another country." 61

From a normative standpoint, however, I believe there are strong grounds to add the responsibility to prevent transnational terrorism (RtoPT) to norms that nations are expected to uphold. If a state fails to honor this responsibility, it seems morally appropriate for the attacked nation to respond with 
counterterrorism measures within the territory of a state used as a base and launching pad by the attackers. ${ }^{62}$ That is, sovereignty should be defined down one more notch; nations should add one more responsibility to maintaining their status as good citizens of the nascent global community.

Behind the arguments that follow in support of RtoPT is the rather basic moral intuition that if terrorists do not respect international borders (by attacking across them), then those who respond to their attacks need not do so either. This intuition is supported here by a new application of a very widely respected normative principle, the Golden Rule. It holds that you should expect others to treat you the same way you treat them. To test this intuition, I suggest one should apply what might be called the "uniform test." If the military of a given nation crossed a border and attacked and terrorized the people of another nation, very few would hold that these troops can hide behind claims of sovereignty for the nation from which the attack stemmed to be spared from counterattacks. If these troops took off their uniforms and engaged in the same kind of attacks, this is hardly a reason for them to be spared. Indeed, as I see it, they are entitled to fewer rights than uniformed fighters. In other words, terrorists have a lower standing than soldiers.

The main reason for this lower standing is that terrorists are violating one of the most profound rules of all armed conflicts, the rule of distinction. The rule of distinction holds that combatants should make special efforts to spare civilians when engaging in armed confrontations. ${ }^{63}$ It is for this reason that the majority of U.S. military aircrafts involved in the fight against ISIS are returning to their base without dropping their bombs or are dropping them on low-value targets. ${ }^{64}$ Responding forces often cannot effectively eliminate combatants who masquerade as civilians and hide among them without killing some innocent civilians, which is a major reason why the U.S. military has done so poorly in Afghanistan and Iraq. ${ }^{65}$ The U.S. military has a five-page, single-spaced list of targets that may not be hit or may be hit only after consultations with high-ranking officials, or even the White House. At various points, American commanders have denied artillery or close air support to beleaguered American troops over concerns that civilians may be hit. In addition, they have ordered American soldiers not to fire until they are hit first. ${ }^{66}$ True, there has nevertheless been considerable "collateral damage." However, a large part of these deaths can directly be attributed to the actions of terrorists who pose as civilians; use unmarked vehicles; and fire from civilian homes, mosques, and schools. Indeed, there can be little doubt that if terrorists abided by the rule of distinction-separating themselves 
from the civilian population and marking themselves, their encampments, and their vehicles-there would be much less collateral damage.

The main counterargument to the RtoPT is that armies are under the control of the government of a given nation and hence can be held accountable for their acts but that is not the case for terrorists. Thus, the sovereignty of the nations from which terrorists attack should be respected. However, one should note that there are basically two different situations: one in which states in effect have considerable control over the terrorists and one in which the terrorists act from ungoverned, under-governed, or ill-governed parts of a country (hereafter ungoverned).

True, states rarely admit that the terrorists they launch are their agents. However, in quite a few cases there is considerable evidence that governments help finance terrorists; provide them with intelligence, arms, and other equipment; and, above all, signal which targets to attack and when (as well as when and where to refrain from attacking). In short, to a large extent these governments control the terrorists operating from their soil. Iran and Hezbollah function in this way, as do Pakistan and Lashkar-e-Taiba with attacks on India. U.S. support of the Mujahideen during the Soviet War in Afghanistan can also be characterized this way. In other cases, the connection is weaker and less evident. ${ }^{67}$ The varying degrees of control and involvement by states in support of terrorism suggest that the response should be similarly graded. The less clear it is whether terrorists are state agents, the more warning said state should be given and the more limited the counterstrikes should be. For instance, drones might be used in place of special forces because the latter's involvement is considered a greater violation of sovereignty. Granting concurrent notification might also be considered in such cases.

Indeed, the United States (and several other nations) designates select countries as terrorist-sponsoring states. As determined by the Secretary of State, the United States currently recognizes Iran, Sudan, and Syria as "countries determined . . . to have repeatedly provided support for acts of international terrorism," ${ }^{\prime 68}$ pursuant to Section $6(j)$ of the Export Administration Act, which states that support for acts of international terrorism includes the recurring use of the land, waters, and airspace of the country as a sanctuary for terrorists (for training, financing, and recruitment) or as a transit point. ${ }^{69}$ The government must also expressly consent to, or knowingly allow, tolerate, or disregard such use. As a result of this determination, these countries are subject to restrictions on U.S. foreign assistance, a ban on defense exports and sales, certain controls over exports of dual use items, and 
miscellaneous financial and other restrictions. What I am calling for is simply taking a next step: legitimizing armed responses when the measures already listed do not suffice to stop attacks.

One may argue that this step is not needed because as of 2012 there were thirteen international conventions and protocols that required state parties to criminalize a particular manifestation of international terrorism under domestic law, cooperate in the prevention of terrorist acts, and take action to ensure that offenders are held responsible for their crimes. ${ }^{70}$ However, the enforcement of these conventions relies on international courts, which raises numerous issues that cannot be explored here. Suffice it to say, there have been no signs that this approach could curb transnational terrorism; hence, this task is left to the assaulted nations.

What about terrorists who are based in and launch their attacks from ungoverned parts of a country? The United States does not include these countries on the list of states sponsoring terrorism. According to the United States' Country Reports on Terrorism 2014, terrorist safe havens include "ungoverned, under-governed, or ill-governed physical areas" where terrorists can "organize, plan, raise funds, communicate, recruit, train, transit, and operate in relative security because of inadequate governance capacity, political will, or both." ${ }^{11}$ The report goes on to exclude such territories from the determination of a state as a sponsor of terrorism. This makes sense in one way, but not in another. If a state is not in control of a given area that serves as a base for terrorists, it should not be held responsible for what is happening in this area. Thus, the United States surely should not impose sanctions or cut aid to Pakistan if it tried in good faith to gain control of the ungoverned parts of Waziristan, but failed. However, it does not follow that one ought to spare terrorists in such areas. Attacking terrorists in ungoverned areas is not violating a nation's sovereignty because a national government forfeits such claims by being unable or unwilling to govern these areas. (Sovereignty is defined as having a commanding control of a given territory. If an area is ungoverned, for practical and normative purposes, it is not encompassed in the sovereignty of the government of the state at issue, though I grant that this position is not reflected in current understanding of international law. However, these laws have been changed before, and ought to be changed again accordingly.)

In short, states should be expected to prevent terrorists from using their territories. If they do not or cannot live up to this responsibility, they give up the relevant part of their sovereignty claims. Hence, the international community and, if 


\section{it fails, the countries attacked by terrorists act legitimately when they respond to}

terrorists with force, regardless of on what side of the border these terrorists are found.

\section{NOTES}

${ }^{1}$ G. John Ikenberry, “The Future of the Liberal World Order," Foreign Affairs 90, no. 3 (2011).

2 The historical question whether this conception of sovereignty arose out of the Treaty of Westphalia is the subject of significant debate within the literature. For a concurring view, see Daniel Philpott, Revolutions in Sovereignty: How Ideas Shaped Modern International Relations (Princeton, N.J.: Princeton University Press, 2001), p. 76. For dissenting views, see Daniel Nexon, "Zeitgeist? Neo-idealism and International Political Change," Review of International Political Economy 12, no. 4 (2005), pp. 700-19, and Stephen Krasner, Sovereignty: Organized Hypocrisy (Princeton, N.J.: Princeton University Press, 1999), pp. 20-25.

3 For a recent example, see Romit Guha and Brian Spegele, "China-India Border Tensions Rise," Wall Street Journal, April 26, 2013, online.wsj.com/article/SB10001424127887323789704578446970130137416.html.

${ }^{4}$ Francis Deng et al., Sovereignty as Responsibility: Conflict Management in Africa (Washington, D.C.: Brookings Institution Press, 1996), p. xvi.

${ }^{5}$ Some scholars (e.g., John Ikenberry) hold that the international order centered on Westphalian sovereignty is a decidedly liberal order, while others (e.g., Anne Marie Slaughter) associate the Westphalian model of sovereignty with realism as distinct from a liberal notion of sovereignty under which states have responsibilities, especially to protect their citizens, as well as rights. For Ikenberry's view, see G. John Ikenberry, Liberal Leviathan (Princeton, N.J.: Princeton University Press, 2011). For Slaughter's, see Anne Marie Slaughter, "Sovereignty and Power in a Networked World Order," Stanford Law Review 40 (2004), pp. 283-329, and Anne Marie Slaughter, "Intervention, Libya, and the Future of Sovereignty," Atlantic, September 4, 2011, www.theatlantic.com/international/ archive/2011/09/intervention-libya-and-the-future-of-sovereignty/244537/.

6 Daniel Philpott, "Sovereignty," in Edward N. Zalta, ed., Stanford Encyclopedia of Philosophy (Summer 2010 Edition), plato.stanford.edu/cgi-bin/encyclopedia/archinfo.cgi?entry=sovereignty. See also Jack Goldsmith and Daryl Levinson, "Law for States: International Law, Constitutional Law, Public Law," Harvard Law Review 122, no. 7 (2009), p. 1844.

7 Rome Statute of the International Criminal Court, July 17, 1998.

${ }^{8}$ Charter of the United Nations, June 26, 1945.

9 Philpott, "Sovereignty."

${ }^{10}$ Jacques Maritain, Man and the State (Chicago: University of Chicago Press, 1951).

${ }^{11}$ Krasner, Sovereignty: Organized Hypocrisy, pp. 85-86, 108, 163-75, 180-82, 202-17.

12 Ibid.

${ }^{13}$ Bertrand de Jouvenel, Sovereignty: An Inquiry into the Political Good (Cambridge: Cambridge University Press, 1957).

${ }^{14}$ Hurst Hannum, Autonomy, Sovereignty, and Self-Determination: The Accommodation of Conflicting Rights (Philadelphia: University of Pennsylvania Press, 1990), p. 20.

15 Report of the Secretary-General's High-level Panel on Threats, Challenges and Change, A More Secure World: Our Shared Responsibility (New York: United Nations Department of Public Information, 2004), p. 17.

${ }^{16}$ Philip Bobbitt calls the notion of sovereignty practiced by the UN "translucent" sovereignty and describes it as a form of sovereignty that is afforded to states unless the Security Council says otherwise. Philip Bobbitt, Terror and Consent: The Wars for the Twenty-First Century (New York: Anchor, 2009), p. 454.

17 Bobbitt, Terror and Consent, pp. 453-54.

18 Philpott, "Sovereignty."

19 Michael W. Doyle, "Dialectics of a Global Constitution: The Struggle Over the UN Charter," European Journal of International Relations 18, no. 4 (2012), p. 617.

${ }^{20}$ One might observe a certain similarity between this view and the Kantian view proposed in the article "Perpetual Peace."

212005 World Summit Outcome, "Draft resolution referred to the High-level Plenary Meeting of the General Assembly by the General Assembly at its fifty-ninth session," September 15, 2005, www. who.int/hiv/universalaccess2010/worldsummit.pdf.

${ }^{22}$ Deng et al., Sovereignty as Responsibility.

23 Ibid., p. xvii. 
${ }^{24}$ Gareth Evans and Mohamed Sahnoun et al., The Responsibility to Protect: Report of the International Commission on Intervention and State Sovereignty (Ottawa: International Development Research Centre, 2001), p. 13.

${ }^{25}$ A More Secure World: Our Shared Responsibility (New York: United Nations Department of Public Information, 2004), p. 17.

26 Ibid.

27 Security Council Res. 1674, S/RES/1674, April 28, 2006.

${ }^{28}$ Luke Glanville, "The Responsibility to Protect Beyond Borders," Human Rights Law Review 12, no. 1 (2012), p. 1.

29 Bruce Ackerman, “Obama's Unconstitutional War," Foreign Policy, March 24, 2011; Richard Norton-Taylor, "Libya Campaign 'Has Made UN Missions to Protect Civilians Less Likely," Guardian, March 19, 2012, www.guardian.co.uk/world/2012/mar/19/libya-un-missions-civilians.

${ }^{30}$ Quoted in Luke Glanville, "Darfur and the Responsibilities of Sovereignty," International Journal of Human Rights 15, no. 3 (2011), p. 465.

${ }^{31}$ Deng et al., Sovereignty as Responsibility, p. 223.

${ }^{32}$ Stevie Martin, "Sovereignty and the Responsibility to Protect: Mutually Exclusive or Codependent?" Griffith Law Review 20, no. 1 (2011), p. 160.

33 Philippe Garigue, "Intervention-Sanction and Droit d'ingerence in International Humanitarian Law," International Journal 48, no. 4 (1993), p. 672.

${ }^{34}$ Commission on Global Governance, Our Global Neighborhood: Report of the Commission on Global Governance (New York: Oxford University Press, 1995).

35 A. P. V. Rogers, "Humanitarian Intervention and International Law," Harvard Journal of Law \& Public Policy 27, no. 3 (2004), p. 728; Fernando R. Tesón, "Collective Humanitarian Intervention," Michigan Journal of International Law 17 (1996), p. 324; and Jack Donnelly, "Genocide and Humanitarian Intervention," Journal of Human Rights 1, no. 1 (2002), pp. 100, 101.

${ }^{36}$ United Nations Department of Public Information, "Security Council Approves 'No-Fly Zone' over Libya, Authorizing 'All Necessary Measures' to Protect Civilians, by Vote of 10 in Favour with 5 Abstentions," SC/10200, March 17, 2011, www.un.org/press/en/2011/sc10200.doc.htm.

37 B.S. Chimni, "Forum Replies: A New Humanitarian Council for Humanitarian Interventions?" International Journal of Human Rights 6, no. 1 (2002), p. 107.

${ }^{38}$ Evans and Sahnoun et al., The Responsibility to Protect, p. 31.

39 Ibid., p. 32

40 Touko Piiparinen, "Sovereignty-Building: Three Images of Positive Sovereignty Projected through Responsibility to Protect," Global Change, Peace \& Security 24, no. 3 (2012), p. 410.

${ }^{41}$ Luke Glanville, “The Antecedents of 'Sovereignty as Responsibility,"” European Journal of International Relations 17, no. 2 (2011), p. 234.

42 Adrian Gallagher, "What Constitutes a 'Manifest Failing'? Ambiguous and Inconsistent Terminology in the Responsibility to Protect," International Relations 28, no. 4 (2014).

${ }^{43}$ Louise Arbour, "The Responsibility to Protect as a Duty of Care in International Law and Practice," Review of International Studies 34, no. 3 (2008), pp. 450-52.

44 Ibid.

45 Amitai Etzioni, “The Democratisation Mirage," Survival: Global Politics and Strategy 57, no. 4 (2015).

46 Ikenberry, Liberal Leviathan, p. 250.

47 For example, both China and Russia have endorsed the "Responsibility to Protect," and the two nations (reluctantly) permitted the intervention in Libya by declining to veto the United Nations Security Council's authorization of the use of force in the country. See Dan Bilefsky and Mark Landler, "As U.N. Backs Military Action in Libya, U.S. Role Is Unclear," New York Times, March 17, 2011, www. nytimes.com/2011/03/18/world/africa/18nations.html?pagewanted=all.

${ }^{8}$ Ramesh Thakur, "Law, Legitimacy and United Nations," Melbourne Journal of International Law 11, no. 1 (2010)

49 An ICISS report found, for example, that "in the ten cases where humanitarian claims were made for intervention prior to 1999 'the rhetoric of humanitarianism had been used most stridently in cases where the humanitarian motive was weakest."' Aidan Hehir, "The Responsibility to Protect: 'Sound and Fury Signifying Nothing'? International Relations 24, no. 2 (2010), p. 224.

50 Alex J. Bellamy, “The Responsibility to Protect-Five Years On," Ethics \& International Affairs 24, no. 2 (2010), pp. 143-69; and Alex J. Bellamy “The Responsibility to Protect Turns Ten,” Ethics \& International Affairs 29, no. 2 (2015), pp. 161-85.

${ }^{51}$ Akbar Nasir Khan, "Legality of Targeted Killings by Drone Attacks in Pakistan," Pak Institute for Peace Studies (February 2011). 
52 Mary Ellen O'Connell, "Lawful Use of Combat Drones" (Statement at the Hearing before the Subcommittee on National Security and Foreign Affairs, "Rise of the Drones II: Examining the Legacy of Unmanned Targeting," U.S. House of Representatives, 111th Congress, 2010), fas.org/irp/ congress/2010_hr/042810oconnell.pdf; see also Dana Priest, "Foreign Network at Front of CIA's Terror Fight," Washington Post, November 18, 2005, www.washingtonpost.com/wp-dyn/content/ article/2005/11/17/AR2005111702070_3.html.

53 Chris Woods, "CIA Drone Strikes Violate Pakistan's Sovereignty, Says Senior Diplomat," Guardian, August 3, 2012, www.guardian.co.uk/world/2012/aug/o3/cia-drone-strikes-violate-pakistan.

${ }^{54}$ Mary Ellen O'Connell, "When is a War Not a War? The Myth of the Global War on Terror," ILSA Journal of International \& Comparative Law 12, no. 2 (2005), p. 5.

55 This assumes sovereignty in the Westphalian sense. In an influential book, Stephen Krasner identifies three further notions of sovereignty: international legal sovereignty, which is a property of independent territorial entities that have rights, like entering into contracts; interdependence sovereignty; and domestic sovereignty. On Krasner's view, Westphalian sovereignty captures the idea that states can organize their domestic affairs any way they wish and other states may not intervene in these domestic affairs, which he consider a misnomer and argues has never truly been practiced in international relations. See Krasner, Sovereignty: Organized Hypocrisy.

${ }^{56}$ It is important to note that the Rome Statute of international criminal law authorizes the ICC to prosecute individuals of nonstate, but state-like entities who commit crimes against humanity. Because the ICC does not have a police force, but relies on states to apprehend and arrest individuals suspected of such crimes, this practice does not raise concerns with violations of territorial sovereignty.

57 Security Council Res. 573, S/RES/573, October 4, 1985.

${ }^{58}$ General Assembly Res. 41/38, A/RES/41/38, November 20, 1986.

59 Security Council Res. 1566, S/RES/1566, October 8, 2004.

${ }^{60}$ General Assembly Res. 60/288, A/RES/60/288, September 8, 2006

${ }^{61}$ Christian J. Tams, "The Use of Force against Terrorists," European Journal of International Law 20, no. 2 (2009), pp. 359-97.

${ }^{62}$ A Justice Department white paper states that targeted killings in a foreign nation are "consistent with legal principles of sovereignty and neutrality if [they are] conducted, for example, with the consent of the host nation's government or after a determination that the host nation is unable or unwilling to suppress the threat posed by the individual targeted." Department of Justice, Lawfulness of a Lethal Operation Directed Against a U.S. Citizen Who Is a Senior Operational Leader of Al-Qa'ida or an Associated Force, Washington, D.C., msnbcmedia.msn.com/i/msnbc/sections/news/020413_DOJ_ White_Paper.pdf.

${ }^{63}$ Amitai Etzioni, "A Liberal Communitarian Paradigm for Counterterrorism," Stanford Journal of International Law 49, no. 2 (2013), p. 356.

${ }^{64}$ Eric Schmitt, "U.S. Caution in Strikes Gives ISIS an Edge, Many Iraqis Say," New York Times, May 26, 2015, www.nytimes.com/2015/05/27/world/middleeast/with-isis-in-crosshairs-us-holds-back-to-protectcivilians.html?_r=0.

65 Amitai Etzioni, "COIN: A Study of Strategic Illusion," Small Wars \& Insurgencies 26, no. 3 (2015), pp. $345-76$.

66 Amitai Etzioni, "Rules of Engagement and Abusive Citizens,” Prism 4, no. 4 (2014), pp. 87-102.

67 See, for example, Renée De Nevers, "Sovereignty and Ethical Argument in the Struggle against State Sponsors of Terrorism," Journal of Military Ethics 6, no. 1 (2007), pp. 1-18; and Daniel Byman, "Passive Sponsors of Terrorism," Survival 47, no. 4 (2005), p. 119.

${ }^{68}$ U.S. Department of State, "State Sponsors of Terrorism," www.state.gov/j/ct/list/c14151.htm (accessed 9/16/2015).

69 "Section 2405 Foreign Policy Controls," Cornell University Law School website, www.law.cornell.edu/ uscode/html/uscode50a/usc_sec_50a_00002405----000-.html.

${ }^{70}$ Kimberley N. Trapp. "Holding States Responsible for Terrorism before the International Court of Justice," Journal of international Dispute Settlement 3, no. 2 (2012), pp. 279-98.

${ }^{71}$ U.S. Department of State, Country Reports on Terrorism 2014, June 2015, www.state.gov/documents/ organization/239631.pdf. 